POIMEN : Jurnal Pastoral Konseling

ISSN (Print) : : 2723-5645

ISSN (Online) : 2723-5637

http://ejournal-iakn-manado.ac.id/index.php/poimen

Vol.1, No.2, pp. 1 - 84, Desember 2020

\begin{tabular}{|l|l|}
\hline Diterima & 22 November 2020 \\
\hline Disetujui & 29 Desember 2020 \\
\hline
\end{tabular}

\title{
KEPEKAAN PASTORAL KONSELING BAGI PELAYAN GEREJA KONTEMPORER
}

\author{
Yohan Brek \\ Institut Agama Kristen Negeri Manado \\ Email : yohanbrek@iakn-manado.ac.id
}

\begin{abstract}
ABSTRAK
Penelitian ini difokuskan pada kajian ilmiah tentang Kepekaan Pastoral Konseling bagi Pelayan Gereja Kontemporer di GMIST Filadelfia Manado. Peneliti melihat masih kurangnya pemahaman pelayan gereja untuk melaksanakan pelaynan pastoral konseling dengan baik. Oleh sebab itu penelitian ini bertujuan: a).Untuk mengeksplorasi pemahaman dari Kepekaan Pastoral Konseling bagi Pelayan Gereja Kontemporer, b). Untuk mengeksplorasi pelaksanaan dari Kepekaan Pastoral Konseling bagi Pelayan Gereja Kontemporer dan c). Untuk mengeksplorasi makna yang didapat dari Kepekaan Pastoral Konseling bagi Pelayan Gereja Kontemporer. Penelitian ini menggunakan pendekatan kualitif dengan metode deskriptif secara ilmiah untuk menjadi jalan penelitian dan analisis data yang valid sehubungan dengan penemuan kesimpulan dari hasil penelitian yang dilakukan.
\end{abstract}

Kata Kunci: Kepekaan, Pastoral, Konseling, Gereja, Kontemporer, GMIST, Filadelfia, 


\begin{abstract}
This research is focused on a scientific study of the Pastoral Sensitivity of Counseling for Contemporary Church Servants at GMIST Filadelfia Manado. Researchers see the lack of understanding of church servants to carry out pastoral counseling services properly. Therefore this study aims: a) To explore the understanding of the Pastoral Sensitivity of Counseling for Contemporary Church Servants, b). To explore the implementation of the Pastoral Sensitivity of Counseling for Contemporary Church Ministers and c). To explore the meaning derives from the Pastoral Sensitivity of Counseling for Contemporary Church Ministers. This study uses a qualitative approach with scientific descriptive methods to be a valid way of research and data analysis in connection with finding conclusions from the results of the research conducted.
\end{abstract}

Keywords: Sensitivity, Pastoral, Counseling, Church, Contemporary, GMIST, Filadelfia 
POIMEN: Jurnal Pastoral Konseling Vol. 1, No.2, pp. 14 - 30, Desember 2020

\section{A. PENDAHULUAN}

\section{Latar belakang masalah}

Hadirnya wabah Corona Virus akhir tahun 2019 berawal dari Kota Wuhan di China dan kini masuk di Indonesia telah mengubah semua aktivitas dunia, baik aktivitas pemerintah, swasta maupun aktivitas keagamaan. Akibatnya di mana aktivitas yang biasanya telah berpindah secara terpaksa ke rumah masing-masing penduduk bumi. Tidak terkecuali kenyataan itu juga terjadi di Indonesia dengan slogan stay at home menandakan bahwa kita harus tinggal di rumah dengan tujuan untuk memutuskan mata rantai penyebaran covid-19 dalam pengawasan gugus covid-19 bentukan pemerintah.

Namun seiring dengan adanya perkembangan penyebaran covid-19 yang dianggap tidak berkurang tetapi malah bertambah juga memperhatikan kondisi perekonomian negara dan masyarakat semakin mengalami penurunan, maka dileuarkanlah wacana untuk melaksankaan Adaptasi Kebiasan Baru atau dengan Istilah globalnya New Normal. Suasana adaptasi kebiasan baru ini sebenarnya adalah suatu kebijakan yang diambil pemerintah agar masyarakat dapat kembali melakukan aktivitas dengan normal namun harus dengan disiplin untuk memerhatikan protokol kesehatan yang telah diatur oleh pemerintah.

Dari situasi dan kondisi seperti ini juga pasti sangat mempengaruhi aktivitas pelayanan gereja. Saat covid-19 semua kegiatan peribadahan dan program pelayanan gereja termasuk pelayanan pastoral mengalami keterkejutan mendalam karena terpaksa mau tidak mau harus dilaksanakan di rumah. Secara otomatis gereja secara lembaga mulai dari pusat sampai ke tingkat jemaat melakukan penyesuaikan program kerja pelayanan termasuk pelayanan pastoral. Hal itu harus dilakukan karena untuk menjawab kebutuhan pelayanan yang ada di jemaat masing-masing.

Demikian pula sekarang ketika adanya himbauan pemerintah tentang Adaptasi Kebiasaan Baru (AKB) atau lebih dikenal dengan istilah Era New Normal, yaitu dengan adanya pengaktifan kembali aktivitas kehidupan masyarakat secara normal namun dalam tatanan kebiasan baru yang tetap mematuhi protokol kesehatan sesuai anjuran pemerintah. Situasi ini juga memengaruhi aktivitas pelayanan gereja kontemporer. Dalam menghadapi kondisi new normal ini maka tentunya gereja turut terlibat berkontribusi untuk melakukan penyesuaian kembali 
POIMEN: Jurnal Pastoral Konseling Vol. 1, No.2, pp. 14 - 30, Desember 2020

program pelayanan sesuai kondisi yang ada di daerah masing-masing. Dalam kondisi seperti ini ada berbagai macam pertimbangan dan pilihan gereja dalam melaksanakan pelayanannya. Ada gereja yang sudah menyelenggarakan pelayanan ibadah dengan menghadirkan seluruh anggota jemaatnya. Seperti yang dilakukan disalah satu gereja di Manado Setelah memperhatikan Surat Edaran Gubernur Sulawesi Utara dan Surat Edaran Sinode maka mereka langsung menindak lanjutinya dengan membuka pintu gedung gereja. Gereja ini sudah melaksankan ibadah bersama-sama anggota jemaat dalam gedung ibadah namun tetap memperhatikan protokol kesehatan. Kemudian ada juga gereja yang sampai dengan sekarang belum melaksanakan ibadah bersama di dalam gedung ibadah, melainkan masih melaksanakan ibadah di rumah masing-masing dengan cara menggunakan media sosial melalui livestreaming dengan Facebook atau menggunakan sarana pengeras suara yang dipasang di tempat yang tinggi. Kesemuanya itu dilakukan oleh gereja demi pelaksanaan peribadatan jemaat.

Melihat kondisi pelayanan gereja yang ada sehubungan dengan pelaksanaan pelayanan di era new normal ternyata yang paling diperhatikan dalam pelayanan gereja adalah pelayanan peribadatan bagi jemaat. Gereja memandang bahwa sentral pelayanan gereja adalah ibadah secara seremonial. Padahal gereja lupa bahwa ada salah satu bentuk pelayanan gereja yang kadang kala terabaikan yaitu pelayanan pastoral konseling. Gereja hanya mementingkan seremonial dari peribadatan, sementara bentuk pelayanan lain seperti Pelayanan Pastoral Konseling kurang diperhatikan. Dari hasil observasi yang dilakukan oleh peneliti dibeberapa tempat di wilayah pelayanan Gereja Masehi Injili Sangihe Talaud (GMIST) ditemukan bahwa kurangnya kepekaan pelayanan pastoral konseling dilakukan oleh para pelayan gereja. Hal itu dapat dilihat dari aktivitas pelayanan yang dilaksanakan di jemaat semuanya hanya terpusat pada ibadah dan kegiatan pelayanan pastoral kepada anggota jemaat yang sebenarnya sangat membutuhkan perhatian khusus dari pelayan gereja hampir tidak dilaksanakan. Jika ada anggota jemaat yang berulang tahun pun pelayanan yang dilakukan adalah hanya doa saja, apalagi jika ada anggota jemaat yang sakitpun kurang dilaksanakan pelayanan pastoral konseling. Padahal dengan adanya situasi dan kondisi covid-19 sekarang 
POIMEN: Jurnal Pastoral Konseling Vol. 1, No.2, pp. 14 - 30, Desember 2020

walaupn sudah di new normal justru begitu banyak anggot jemaat yang membutuhkan pertolongan rohani melalui pelayanan pastoral koneling.

Para pelayan gereja seharusnya peka terhadap kebutuhan pelayanan pastoral konseling. Para pelayan gereja haru menyadari bahwa tugas pastoral adalah perintah Tuhan Yesus untuk menjadi gembala dan meneladani Dia sebagai Gembala Yang Baik. Karena itu dalam situasi dan kondisi di era new normal ini maka dibutuhkan Kepekaan Pastoral bagi pelayan gereja kontemporer. Kepekaan pastoral konseling menjadi dasar yang kuat dalam pemenuhan kebutuhan rohani jemaat. Dengan dilatar belakangi oleh pemikiran tersebutlah membuat peneliti tertarik untuk melakukan penelitian dengan judul Kepekaan Pastoral Konseling bagi Pelayan Gereja Kontemporer.

\section{B. DESKRIPSI TEORETIK}

Istilah Pastoral sebenarnya berasal dari kata Latin "pastor” berarti gembala kemudian kata gembala itu juga diartikan dalam kata Yunani "poimen” (M. BonsStorm ,2008:4). Selanjutnya kata penggembalaan juga disebut "poimenika", atau "pastoralia". Oleh karena itu Pelayanan Pastoral sama dengan Penggembalaan (Abineno,2010:9). Dengan demikian stilah Pastoral adalah aktivitas atau kegiatan pelayanan gereja yang dilakukan secara terencana untuk menolong umat atau anggota jemaat baik secara pribadi maupun secara berkelompok baik yang sedang bergumul dengan persoalan-persoalan yang menghimpitnya maupun yang tidak sedang bergumul dengan persoalan-persoalan. Proses pelayanan tersebut di dasari oleh perintah Tuhan Yesus sendiri yaitu Gembalakanlah Domba-dombaku (Yoh.21:15-29); Gembalakanlah kawanan domba Allah (1 Petrus 5:1-11) dan Menggembalakan jemaat Allah (Kisah 20:28). Pengistilahan Pastoral ini erat hubungannya dengan pribadi Yesus Kristus sendiri dan karya-Nya sebagai Pastor sejati atau Gambala yang baik (Yoh.10) Dalam pelayanan Pastoral yang efektif sangat membutuhkan proses konseling. Karena antara Pastoral dengan Konseling mempunyai hubungan yang sangat melengkapi dan tidak terpisahkan. Dimana ada kegiatan pastoral maka disitu pula ada konseling, sebaliknya di mana ada kegiatan konseling kristen maka disitu pula ada pelayanan pastoral. 
Selanjutnya isitlah Konseling berasal dari kata kerja Inggris kuno "counseil" atau "conseil" dalam bahasa Perancis. Dalam bahasa Latin "consillium" atau "consulere" yang berarti "merundingkan" (Wiryasaputra,2014:74). Dalam perkembangan selanjutnya kata konseling mengandung arti membimbing, mendampingi, menuntun dan mengarahkan. Dalam pengertian pula bahwa konseling adalah pelayanan yang menolong jemaat yang dilakukan dalam bentuk komunikasi timbal balik (Tu'u, 2007:18). Karena itu kata Konseling adalah hubungan timbal balik antara dua individu yakni konselor yang berusaha menolong atau membimbing dan klien yang membutuhkan bimbingan dalam suasana percakapan yang serasi / tepat, yang memungkinkan klien mengenali dirinya, mengerti apa yang sedang terjadi dengan dirinya, dan memiliki kemampuan untuk melihat dan mencapai tujuan hidupnya dalam relasi dan tanggung-jawabnya kepada Tuhan, sesuai dengan kemampuan dan talenta yang diberikan Tuhan kepadanya ( Yakub B. Susabda, 2007:101).

Pastoral Konseling adalah hubungan timbal balik antara hamba Tuhan sebagai konselor dengan jemaat sebagai konselinya. Konselor membimbing konseli dalam suatu suasana percakapan konseling yang ideal, yang memungkinkan konseli betul-betul mengerti apa yang terjadi pada dirinya sehingga ia mampu melihat tujuan hidupnya dan mampu mencapai tujuan itu dengan kekuatan dan kemampuan dari Tuhan (Tu'u, 2007:24). Tujuan akhir dari pelaksanaan pelayanan Konseling Pastoral adalah agar anggota jemaat yang dilayani dapat mengerti dan memahami tentang pergumulannya dan keluar dari pergumulan yang ia hadapi dan menyadari bahwa betapa berharganya dia dihadapan Allah. Konseling pastoral berperan dalam suatu krisis dan kemalangan hidup, baik itu individu maupun keluarga, bahkan dalam krisis perubahan sosial dalam masyarakat (Engel,2016:11). Karena itu inti utama yang diharapkan dalam konseling pastoral adalah pemulihan secara holistik baik fisik, psikis, sosial dan spiritual. Sehingga proses pemulihan itu didapatkan dan dimulai dari dirinya sendiri.

\section{Tujuan Pastoral Konseling}

Untuk mencermati lebih jelas tentang teori Pastoral Konseling maka tentunya perlu didesekripsikan terlebih dahulu tujuan pastoral konseling. Dalam hal ini 
POIMEN: Jurnal Pastoral Konseling Vol. 1, No.2, pp. 14 - 30, Desember 2020

maka peneliti menggunakan beberapa uraian dari Totok Wiryasaputra (2014: 97) tentang tujuan konseling pastoral meliputi :

1) Membantu konseli mengalami pengalamannya dan menerima kenyataan yang ada. Yang diharapkan dari tujuan ini adalah untuk membantu konselig atau orang yang dilayani agar memahami, mengerti dan menyadari dengan sendirinya bahwa penyelesaian krisis yang ia hadapi tergantung dari dirinya sendiri untuk mengalaminya dan menerimanya. Sehingga proses pemulihan terjadi oleh konseli sendiri secara utuh.

2) Membantu konseli mengungkapkan diri secara penuh dan utuh. Selanjutnya yang diharapkan dari tujuan ini adalah agar konseli atau orang yang dilayani dapat secara spontan, kreatif dan efektif mengekspresikan perasaan yang sesungguhnya yang membantu dia untuk proses pemulihan yang utuh

3) Membantu konseli berubah, bertumbuh dan berfungsi maksimal. Kemudian yang diharapkan dari tujuan ini adalah agar konseli mengalami perubahan, dan bertumbuh serta berfungsi secara maksimal baik bagi sesama manusai dan lingkungannya.

4) Membantu konseli menciptakan komunikasi yang sehat. Yang diharapkan dari tujuan ini adalah agar dalam proses konseling pastoral tercipta suasana yang sehat dan terfokus untuk menghindari adanya timbul percakapan yang menyimpang dari tujuan bersama konseling pastoral

5) Membantu konseli bertingkah laku baru. Yang diharapkan dari tujuan ini adalah agar suasana percakapan konseling pastoral dapat terjadi dengan rasa nyaman tidak saling curiga dan konseli atau orang yang dilayani mengalami perilaku baru dalam artian jika semula dia terus diam maka selanjutnya dia lebih ceria.

6) Membantu konseli bertahan dalam situasi baru. Yang diharapkan dalam tujuan ini adalah agar mengalami keasadaran akan pengalaman krisis kehidupannya dan bersedia dengan ikhlas menerima kenyataan yang sesungguhnya.

7) Membantu konseli menghilangkan gejala disfungsional. Yang diharapkan dari tujuan ini adalah kemampuan konselor pastoral untuk membimbing konseli agar menghilangkan gejala disfungsional, sehiggan proses konseling pastoral dapat berjalan dengan normal dan baik sesuai yang diharapkan. 


\section{Fungsi Pastoral Konseling}

Fungsi pastoral konseling merupakan dasar bagi peneliti dan pelayan pastoral konseling dalam mengembangkan pelayanan dan penelitian dibidang pastoral konseling. Oleh sebab itu pada bagian ini peneliti akan mendeskripsikan tentang fungsi pastoral konseling seperti yang telah diuraikan oleh Aart Van Beek (2007:13-16) sebagai berikut :

1) Fungsi Membimbing

Fungsi membimbing penting dilakukan dalam kerangka untuk menolong dan mendampingi seseorang. Konselor melakukan pelayanan pendampingan kepada klien untuk memilih dan mengambil keputusan tentang apa yang akan ditempuh atau apa yang menjadi masa depannya. Konselor mengemukakan beberapa kemungkinan yang bertanggung jawab dengan segala risikonya, sambil membimbing orang kearah pemilihan yang berguna. Akan tetapi pengambilan keputusan tentang masa depan ataupun mengubah dan memperbaiki tingkah laku tertentu atau kebiasaan tertentu, tetap di tangan klien.

2) Fungsi Mendamaikan / Memperbaiki Hubungan

Salah satu kebutuhan manusia untuk hidup dan merasa aman adalah adanya hubungan yang baik dengan sesama, apakah dengan orang yang dekat maupun dengan orang banyak. Apabila hubungan tersebut terganggu, maka terjadilah penderitaan yang berpengaruh pada masalah emosional. Dengan demikian kehadiran konselor dapat berfungsi sebagai perantara untuk memperbaiki hubungan yang rusak dan terganggu.

3) Fungsi Menopang / Menyokong

Seringkali kita diperhadapkan kepada seseorang yang tiba-tiba mengalami krisis mendalam. Dan seringkali pada saat itu kita tidak dapat berbuat banyak untuk menolong. Akan tetapi kehadiran kita adalah untuk membantu mereka bertahan dalam situasi krisis yang bagaimanapun beratnya. Sokongan berupa kehadiran dan sapaan yang meneduhkan dan sikap yang terbuka, akan mengurangi penderitaan yang begitu memukul. 


\section{4) Fungsi Menyembuhkan}

Fungsi penyembuhan ini penting dalam arti bahwa melalui pendampingan yang berisi kasih sayang, rela mendengarkan segala keluhan batin, dan kepedulian yang tinggi akan membuat seseorang yang sedang menderita mengalami rasa aman dan kelegaan sebagai pintu masuk ke arah penyembuhan yang sebenarnya.

Fungsi ini penting terutama bagi mereka yang mengalami dukacita dan luka batin. Dalam hal ini, hal yang dianggap dapat menolong adalah bagaimana konselor melalui pendekatannya mengusahakan penderita untuk mengungkapkan perasaan batinnya yang tertekan. Melalui interaksi ini kita membawanya pada hubungan imannya dengan Tuhan melalui doa, pembacaan Alkitab, yang sekaligus sebagai sarana penyembuhan batin.

\section{5) Fungsi Mengasuh}

Hidup berarti bertumbuh dan berkembang. Perkembangan itu meliputi aspek emosional, cara berpikir, motivasi dan kemauan, tingkah laku, kehidupan rohani, dalam interaksi dan sebagainya. Demikianlah dalam hal menolong mereka yang memerlukan pertolongan, kita perlu melihat kira-kira potensi apa yang dapat menumbuh-kembangkan kehidupannya sebagai kekuatan yang dapat diandalkannya untuk tetap melanjutkan kehidupan.

6) Fungsi Mengutuhkan

Fungsi ini adalah fungsi pusat, karena sekaligus merupakan tujuan utama, yaitu pengutuhan kehidupan manusia dalam segala aspek kehidupannya, yakni fisik, sosial, mental, dan spiritual. Karena bila seseorang mengalami masalah/ penderitaan maka aspek-aspek itu tercabik-cabik. Karena itu fungsi mengutuhkan sangat dibutuhkan dalam kerangka untuk menghasilkan proses pemulihan yang holistik. Dalam konteks fungsi pastoral ini maka sebenarnya pelayanan pastoral itu holistik.

Selain Fungsi yang telah diuraikan diatas selanjutnya Totok Wiryasaputra (2019:193) juga telah menambahkan dua fungsi konseling pastoral yaitu: pertama, fungsi memberdayakan (empowering).Dimana Fungsi ini untuk membantu konseli menjadi penolong bagi dirinya sendiri di masa yang akan datang pada waktu menghadapi kesulitan. Konseli berdaya, mandiri, dan tidak selalu tergantung pada konselor. Fungsi ini juga dipakai untuk membantu konseli menjadi menolong bagi 
orang lain yang mendapat kesulitan. Kemudian kedua, fungsi mentransformasi yaitu ketika konseli secara individual telah sembuh, persoalannya telah selesai, berdaya, berguna secara maksimal bagi sesama dan lingkungannya, memang micro purpose - short-term purpose - tujuan jangka pendek konseling pastoral telah tuntas.

\section{METODOLOGI}

Setiap karya tulis ilmiah tetap dirahkan pada pelaksanaan dengan metode penelitian. Karena itu penelitian merupakan suatu kegiatan ilmiah yang sangat penting bagi pengembangan ilmu dan bagi pemecahan suatu masalah. (Djam'an Satori \& Aan Komariah, 2014:1)

\section{Metode dan Pendekatan Penelitian}

Dalam kerangka menjamin keabsahan dan kebenaran dalam ilmu dan pengetahuan, maka digunakanlah metode yang akan dipakai dalam mengumpulkan data. Karena itu metode yang nanti akan digunakan dalam penelitian ini adalah metode penelitian deskriptif. Menurut Moh. Nazir : Metode deskriptif tujuannya untuk membuat gambaran atau lukisan secara sistematik, faktual dan akurat mengenai fakta-fakta, sifat-sifat serta hubungan atau fenomena yang diselidiki (Moh,Nazir, 1995:63). Dengan metode penelitian ini peneliti menggunakan pendekatan kualitatif "sebagai prosedur penelitian yang menghasilkan data deskriptif berupa kata-kata tertulis atau lisan dari orang-orang dan perilaku yang dapat diamati” (Bogdan dan Taylor, 1975:5 dalam Sudarta, 1997:62).

\section{Tempat dan Waktu Penelitian}

a. Yang menjadi sasaran utama dalam penelitian adalah "social situation" terdiri tiga elemen penting yaitu: tempat (place), pelaku/orang (actors) dan aktivitas (activity). Tiga element tersebut dinamakan obyek penelitian. (Sugiyono, 2011; 297). Sasaran pertama adalah Tempat penelitian yaitu Gereja Masehi Injili Sangihe Talaud (GMIST) Jemaat Filadelfia Manado dan Sasaran penelitian kedua adalah pelaku/orang yang diteliti yaitu para pelayan gereja dan Sasaran penelitian yang ketiga adalah Aktivitas yaitu 
semua jenis aktivitas pelaku/orang yang diteliti dan kegiatan atau program pelayanan gereja.

b. Waktu yang digunakan untuk penelitian ini dimulai sejak pelaksanaan yaitu bulan Juli sampai November 2020

\section{Instrumen Penelitian}

Sebagaimana peneliti telah menggunakan pendekatan kualitatif di mana terdapat dua Instrumen Penelitian yaitu Instrumen Utama dan Instrumen Penunjang yaitu :

a. Instrumen Utama yaitu Peneliti sendiri dan bertugas "menetapkan fokus penelitian, memilih informan sebagai sumber data, melakukan pengumpulan data, menilai kualitas data, analisis data, menafsirkan data dan membuat kesimpulan”. (Sugiyono, 2011:306)

b. Instrumen Penunjang yaitu : Catatan Harian Lapangan, Daftar Pertanyaan, Alat tulis, Alat Recorder, Kamera Foto, Video Recorder.

\section{Sumber Data Penelitian}

Sumber data yang digunakan oleh peneliti dalam penelitian ini pertama, sumber data utamanya adalah persepsi dan praktek yang oleh Moleong menyebutnya "kata-kata dan tindakan" (L.J. Moleong, 2002:112), maksudnya katakata dari orang yang diamati dan diwawancarai. kedua, sumber data tambahan dari sumber tertulis seperti Buku ilmiah, majalah ilmiah, jurnal, dokumen resmi, disertasi,tesis, dan lainnya juga sumber data penunjang penelitian seperti foto, video, dan rekaman.

\section{Prosedur dan Teknik Pengumpulan data}

Dalam penelitian ini juga peneliti menggunakan teknik pengumpulan data sebagai berikut :

1. Observasi Partisipatif

2. Wawancara (Interview)

3. Dokumentasi

\section{Teknik Analisa data}

Bada bagian ini data-data yang diperoleh dari berbagai sumber yaitu observasi, , wawancara, dan dokumentasi yang ditulis dalam catatan harian lapangan serta berbagai sumber resmi setelah dibaca, dipelajari dan ditelaah kemudian di analisis. 
Sugiyono menyatakan bahwa "analisis data dalam penelitian kualitatif dilakukan sejak sebelum memasuki lapangan, selama di lapangan dan setelah selesai di lapangan" (Sugiyono, 2011:336). Analisis data dilakukan oleh para peneliti agar mendapatkan makna yang terkandung dalam sebuah data. Sehigga interpretasinya tidak sekadar deskripsi belaka. (Djam'an Satori \& Aan Komariah ,2014:199). Karena itu saat memulai proses penelitian dari observasi awal maka proses analisis data pun sudah dimulai oleh peneliti.

\section{HASIL DAN PEMBAHASAN}

Berdasarkan hasil penelitian yang telah dilakukan peneliti di mana mengacu pada metodologi penelitian serta memperhatikan deskripsi teoretik tentang Pastoral Konseling berdasarkan Tujuan dan Fungsinya, maka pada bagian ini peneliti akan mendeskripsikan hasil dan pembahasan sebagai berikut :

\section{Dasar Kepekaan Pastoral Konseling}

\section{a. Perintah Tuhan Yesus}

Pelayanan Pastoral Konseling di dalam gereja kontemporer adalah tugas penting yang merupakan perintah langsung Tuhan Yesus bagi gereja untuk dilaksanakan secara baik dan bertanggung jawab. Sebagai pelayan harus mematuhi keterpanggilannya untuk melaksanakan pelayanan pastoral konseling kepada anggota jemaat dengan rajin karena itu merupakan perintah Tuhan Yesus (SL, LM, NS Wawancara, 12-09-20). Perintah untuk melaksanakan pelayanan pastoral konseling dalam Alkitab jelas tertuang dalam Yohanes 10:15-29 yaitu Gembalakanlah domba-dombaKu, kemudian dalam 1 Petrus 5:1-11 Gembalakanlah kawanan domba Allah, selanjutnya dalam Kisah Para Rasul 20:28 Menggembalakan jemaat Allah.

\section{b. Melayani dengan Kasih}

Cara yang paling tepat untuk melaksanakan tugas pelayanan pastoral konseling kepada anggota jemaat adalah pelayanan dengan kasih. Dengan kasih maka seorang pelayan melaksanakan pelayanannya dengan sunggu-sungguh, tidak terpaksa melainkan dengan ketulusan hati dan merupakan panggilan jiwa yang 
POIMEN: Jurnal Pastoral Konseling Vol. 1, No.2, pp. 14 - 30, Desember 2020

luhur untuk menolong orang lain atau anggota jemaat yang membutuhkan (DK, SK, KK, Wawancara, 8-10-2020). Dalam Yohanes 3:16 sangat jelas diuraikan bahwa Allah sangat mengasihi manusia dan dunia ini sehingga Ia mengaruniakan anakNya yang tunggal Yesus Kristus ke dalam dunia ini untuk menyelamatkannya. Kasih Allah menjadi dasar penting dalam pelaksanaan pelayanan pastoral konseling bagi pelayan gereja kontemporer. Karena kasih itu sabar dan murah hati, ia tidak cemburu, tidak memegahkan diri dan tidak sombong...Kasih tidak berkesudahan; nubuat akan berakhir, bahasa roh akan berhenti, pengetahuan akan lenyap (1 Korintus 13:4-8). Hal ini menunjukan bahwa Kasih merupakan titik dasar yang seharusnya ada dalam hati manusia yang diimplementasikan untuk menjalani kehidupan.

\section{c. Empati}

Empati adalah keadaan yang membuat seseorang merasa atau mengidentifikasi dirinya dalam keadaan perasaan atau pikiran yang sama dengan orang atau kelompok lain. Dengan demikian empati dapat dirumuskan sebagai suatu tindakan yang dilakukan seseorang untuk menolong orang lain dengan melihat dan merasakannya dari pihak pendeirita. Seorang pelayan pastoral konseling harus berada pada posisi penderita atau posisi orang yang dilayani sehingga dengan demikian pelayan dapat memahami berat ringannya pergumulan jemaat. Tentu yang menjaidi titik dasar dalam pelayanan pastoral konseling adalah Kasih Yesus Kristus. Empati merupakan tidakan Kepekaan Pastoral Konseling. Orang yang Peka terhadap pergumulan jemaatnya adalah orang yang mampu melaksanakan empati.

\section{Daya Kepekaan Pastoral Konseling}

\section{a. Sensitivitas Pelayanan Pastoral Konseling}

Sensitivitas Pelayanan Pastoral Konseling adalah kemampuan secara cepat menerima rangsangan kebutuhan pelayanan pastoral konseling dalam jemaat. Anggota jemaat sebenarnya sangat membutuhkan sentuhan-sentuhan pelayanan pastoral yang lebih efektif dan kreatif namun yang menjadi kendala adalah apakah kerinduan anggota jemaat tersebut dapat dipenuh sepenuhnya oleh para pelayan atau tidak. Karena itu dalam Kepekaan Pastoral Konseling, maka sensivitas 
POIMEN: Jurnal Pastoral Konseling Vol. 1, No.2, pp. 14 - 30, Desember 2020

pelayanan pastoral itu sangatlah penting untuk diperhatikan dan dipraktekkan oleh pelayan gereja kontemporer.

Dalam sensitivitas pastoral konseling, terdapat daya kepekaan yang cepat tanggap melihat kebutuhan pelayanan jemaat. Seorang pelayan gereja kontemporer mempunyai kemampuan secara cepat dan tepat untuk menjawab dan mengimplementasikan semua kualitas sikap dan keterampilan pastoral konseling sesuai dengan fungsinya bagi kebutuhan jemaat kontemporer.

\section{b. Sensibilitas Pelayanan Pastoral Konseling}

Sensibilitas pelayanan pastoral konseling adalah suatu kemampuan secara cepat menafsirkan rangsangan kebutuhan pelayanan pastoral konseling baik secara internal maupun secara eksternal. Daya sensibilitas ini adalah tindak lanjut dari daya sensitivitas, di mana saat seorang pelayan gereja, menemukan kebutuhan pelayanan jemaat, kemudian secara cermat dan kreatif seorang pelayan gereja melakukan penafsiran terhadap kebutuhan pelayanan dengan menggunakan standar sikap, keterampilan dan fungsi pastoral konseling dalam penanganannya.

\section{c. Suseptibilitas Pelayanan Pastoral Konseling}

Suseptibilitas Pelayanan Pastoral Konseling adalah kemampuan secara cepat merespons kebutuhan pelayanan pastoral konseling dengan melakukan Style Pastoral Konseling. Setelah dilakukan penafsiran yang cermat terhadap kebutuhan pelayanan maka, seorang pelayan gereja tentunya wajib merespons kebutuhan pelayanan itu dengan style pastoral konseling. Style pastoral konseling adalah kemampuan untuk menggunakan metode, teknik dan pendekatan pastoral konseling sesuai dengan fungsi-fungsi pastoral konseling itu sendiri. Karena itu peranan seorang pelayan gereja untuk cepat dan cermat merespons kebutuhan pelayanan sangat diharapkan dalam pelayanan pastoral konseling.

\section{d. Aksesibilitas Pelayanan Pastoral Konseling}

Aksesibilitas Pelayanan Pastoral Konseling adalah kemampuan secara cepat mengakses style pastoral konseling sesuai kebutuhan pelayanan pastoral konseling. Dalam aksesibilitas pastoral konseling tidak hanya menjadi pelayanan satu arah dalam pengertian yaitu bahwa tugas itu hanya dapat dipraktekkan oleh konselor 
atau pelayan gereja saja, dan konseli atau jemaat yang dilayani secara pasif menunggu dilaksanakannya pelayanan pastoral konseling. Melainkan, dalam aksesibilitas pastoral konseling adalah kegiatan pelayanan proaktif dua sisi, baik oleh konselor atau pelayan gereja maupun oleh konseli sendiri diberikan kebebasan untuk mengakses pelayanan pastoral itu sendiri. Hal inilah yang menjadi kebutuhan pelayanan gereja kontemporer.

\section{Capaian Kepekaan Pastoral Konseling menuju Kesehatan Holistik}

a. Fisik adalah salah satu aspek penting dalam pemenuhan capaian kepekaan pastoral konseling menuju kesehatan holistik, manusia dengan eksistensi realnya ada karena aspek fisiknya. Sehingga itu untuk menuju kesehatsan holistik maka tentunya aspek fisik juga harus mengalami kesehatan. Aspek fisik beruhubungan dengan tugas tenaga medis/kesehatan.

b. Psikis merupakan salah satu aspek yang menetukan dalam aktivitas manusia secara baik dan sehat. Karena fisik sehat juga psikis harus sehat kerana itu aspek ini penting diperhatikan dalam pelayanan kepekaan pastoral konseling. Aspek Psikis berhubungan dengan tugas Psikolog dan Psikiater

c. Sosial adalah aspek interaksi manusia dengan manusia yang lain. Jika interaksinya baik dan sehat maka tentu juga menetukan bahwa seseorang akan mengalami kesehatan. Aspek sosial berhubungan dengan tugas sosiolog

d. Spiritual adalah salah satu aspek yang tidak kalah penting, karena baik fisik, psikis maupun sosial yang sudah mengalami kesehatan namun belum lengkap secara holistik jika spiritualitasnya tidak sehat, karena itu aspek spiritual sangat menetukan seseorang mengalami kesehatan holistik. Aspek Spiritual berhubungan dengan tugas konselor pastoral atau pelayan gereja. 
POIMEN: Jurnal Pastoral Konseling Vol. 1, No.2, pp. 14 - 30, Desember 2020

\section{E. PENUTUP}

Pelayan Khsus memahami bahwa sentral pelayanan gereja adalah pelaksanaan ibadah secara seremonial misalnya ibadah minggu, ibadah KWP/Kolom, ibadah Pelayanan kategorial. Hal ini mengakibatkan bahwa adanya kurang pemahaman tentang pelayanan pastoral konseling terhadap jemaat. Kurangnya pemahaman tentang pelayanan pastoral konseling ini mengakibatkan kurangnya kepekaan pastoral konseling oleh pelayan gereja dalam gereja kontemporer

Dalam konteks kontemporer maka sangatlah dibutuhkan kepekaan pastoral konseling pagi pelayan gereja. Kepekaan pastoral konseling dapat dilaksanakan dengan bai apabila memperhatikan Dasar Kepekaan pastoral, Daya Kepekaan Pastoral dan Capaian Kepekaan Pastoral.

\section{DAFTAR PUSTAKA}

Aart Van Beek, Pendampingan Pastoral ,Jakarta : BPK Gunung Mulia, 2007.

Abineno, J. L. Ch, Pedoman Praktis Untuk Pelayanan Pastoral (Jakarta : BPK Gunung Mulia, 2010

Moleong, LJ, Metodologi Penelitian Kualitatif, Bandung: Remaja Karya, 1989

Nazir, Moh, Metode Penelitian, Jakarta : Ghalia-Indonesia, 1985

Satori, Djam'an \& Komariah, Aan, Metodologi Penelitian Kualitatif, Bandung : ALFABETA, cv, 2014

Storm, M. Bons, Apakah Pengembalaan itu? Jakarta : BPK Gunung Mulia, 2008

Sudarta., Metodologi Penelitian Filsafat, Jakarta : PT. Raja Grafindo Persada, 1997

Sugiyono, Metode Penelitian Pendidikan; Pendekatan Kuantitatif, Kualitatif, dan $R \& D$, Bandung : Alfabeta, 2011

Susabda, Yakub B., Pelayanan Konseling Melalui Telepon Yogyakarta : ANDI, 2007 
POIMEN: Jurnal Pastoral Konseling Vol. 1, No.2, pp. 14 - 30, Desember 2020

Taylor, Bogdan, (1975:5), dikutip oleh Sudarta, Metodologi Penelitian Filsafat, Jakarta: PT Raja Grafindo Persada, 1997

Tu'u, Tulus, Dasar-dasar Konseling Kristen Yogyakarta : ANDI, 2007

Wiryasaputra, Totok,S, Pengantar Konseling Pastoral, Salatiga: Diandra Pustaka Indonesia, 2014

Konseling Pastoral di Era Milenial, Yogyakarta: Seven

Books, 2019 